\title{
Raskauden ja synnytyksen aiheuttamat kustannukset
}

Valtiot. kand. ELINA VISURI

Väestöpoliittinen tutkimuslaitos

Sosiaalinen lainsäädäntömme antaa odottavan äidin ja synnyttäjän taloudelliseksi tukemiseksi ja hänen terveytensä suojelemiseksi useita merkittäviä etuja. Kunnallisissa äitiysneuvoloissa voi jokainen äiti saada täysin maksuttomasti lääkärin ja kätilön suorittamat tarkastukset. Äitiyshuolto näissä neuvoloissa onkin ulottunut lähes jokaiseen synnyttäjään, sillä v. 1958 oli noin $95 \%$ kaikista synnyttäjistä äitiysneuvoloiden kirjoissa. Kunnankätilöt käyvät myös kotona odottavaa tai synnyttänyttä äitiä ja hänen lastaan katsomassa. Kotikäyntejä oli v. 1958 keskimäärin lähes viisi käyntiä synnyttäjää kohti (SVT XI:6).

Synnytyshoidon saamista helpottaa synnytyslaitosmaksujen suhteellinen alhaisuus valtion ja kuntien ottaessa osaa laitosten kustannuksiin. Kunnankätilöiden hoitamat synnytykset, joita v. 1958 oli $13 \%$ kaikista, ovat maksuttomia. Synnytys ilman koulutettua apua on enää harvinainen poikkeus, vain vähemmän kuin kolme tuhannesta synnytyksestä tapahtuu muun kuin lääkärin tai kätilön hoitamana. Terveydenhoitoon kohdistuvaa tukea täydentää äitiysavustus, jolla pyritään huojentamaan erityisesti lapsen vaatetuksesta aiheutuvia menoja. Aitiysavustuksen, arvoltaan 4500 mk, saa jokainen synnyttäjä, joka on käynyt lääkärin, kätilön tai äitiysneuvolan tarkastuksessa ennen neljännen raskauskuukauden päättymistä ja joka anoo tätä avustusta.

Kunnalliset kodinhoitajat antavat apuaan lapsiperheille äidin synnytyslaitoksella ollessa. Perheen varallisuudesta riippuen on kodinhoitajan apu joko kokonaan tai osittain maksuton. Synnyttäjälle tarpeellisen lepoajan turvaamiseen tähtää myös lainsäädäntö palkkatyössä käyvän synnyttäjän pakollisesta synnytyslevosta. Kauppaliikkeissä ja toimistoissa työskentelevien synnytyslepo on lailla säädetty 6 viikon pituiseksi, kun taas teollisuusammateissa asetus kieltää pitämästä naista työssä neljänä ensimmäisenä viikkona synnytyksen jälkeen. Myös eräiden ammattialojen työehtosopimuksiin on sisällytetty määräyksiä synnytyslomien pituudesta. Työstä poissaolon ajalta saavat palkkaa kuitenkin vain eräät työntekijäryhmät, etupäässä valtion ja kuntien viran ja toimenhaltijat, joiden synnytysloma on kahden kuukauden pituinen.

Suunnitteilla olevassa sairausvakuutusjärjestelmässä on korvaukseen oikeuttaviin sairauskuluihin luettu myös raskauden ja synnytyksen aiheut- 
tamat kustannukset ja työansionmenetys. Sairausvakuutuskomitean mietinnön (Komiteanmietintö 1959, 6) mukaan tulisivat kokonaan korvattaviksi sairaalahoidosta aiheutuneet kulut sekä osittain takaisin vakuutetulle maksettaviksi lääkäri-, laboratorio- ja lääkekulut sekä hoidosta aiheutuneet matkakustannukset. Palkanmenetyksen vastineeksi maksettaisiin kaikille synnyttäjille 10800 markan suuruinen äitiysraha, joka vastaa 72 päivän sairaspäivärahaa, sekä lisäpäivärahaa niille synnyttäjille, joilla edellisenä vuonna on ollut ansiotuloja yli $100000 \mathrm{mk}$.

Uuden lainsäädännön valmistelu on antanut aihetta tarkastella niitä raskauden ja synnytyksen aiheuttamia kustannuksia, jotka nykyisin vielä jäävät perheiden kannettaviksi. Kun synnytyskustannuksiin laajasti ottaen voidaan sisällyttää myös ansionmenetykset - kuten sairausvakuutusesityksessäkin on tehty —, on synnyttäjän saamia lomaetuja ja työstä poissaoloa verrattu sekä nykyisen lainsäädännön asettamiin normeihin että uuteen komitean ehdotukseen. Perustan tarkastelulle antavat 1600:lta synnyttäjältä saadut tiedot, jotka kerättiin Väestöliiton toimesta alkuvuodesta 1959 kunnankätilöiden toimiessa kyselylomakkeiden välittäjinä. Kootuista tiedoista on esitetty lyhyt yhteenveto Sosiaalisessa Aikakauskirjassa 11-12, 1960 (Visuri, 1960).

\section{Tutkimuksen suoritus}

Tutkimusta varten suoritettiin kunnista otos siten, että saatiin haastateltaviksi marraskuussa 1958 synnyttäneistä äitiysneuvoloiden kirjoissa olevista äideistä maalaiskunnissa $35 \%$ ja kaupunki- ja kauppalakunnissa Helsinkiä lukuunottamatta $20 \%$. Helsingissä valittiin tutkimuksen kohteeksi umpimähkäisesti $50 \%$ yleisissä synnytyslaitoksissa ja -osastoissa samana aikana synnyttäneistä potilaista, jotka olivat kaupungin äitiysneuvoloiden kirjoissa. Lapin läänin maalaiskunnat ja saaristokunnat jätettiin tutkimuksen ulkopuolelle.

Maalaiskunnat jaettiin otosta varten kuntien varallisuusluokittelun ja maatalousvaltaisuusasteen perusteella kahdeksaan luokkaan sekä kukin näistä vielä kunnassa v. 1956 syntyneiden lasten lukumäärän mukaan kahteen luokkaan. Näin saaduista 16 luokasta valittiin umpimähkäisesti 149 tutkimuskuntaa. Kaupungit ja kauppalat ryhmiteltiin suuruuden ja sijainnin mukaan ja niistä poimittiin 15 .

Kaikkiaan palautettiin maalaiskunnista 1164 kyselylomaketta eli $90 \%$ tutkimuksen kohteille osoitetuista. Helsingissä antoi vastauksensa tiedusteluun 147 äitiä, $81 \%$ tutkimukseen valituista, ja muissa kaupunkikunnissa 302 eli $91 \%$.

Raskauden ja synnytyksen aiheuttamiksi kustannuksiksi katsottiin kaikki raskauden, synnytyksen ja lapsivuodeajan aiheuttamat välittömät rahamenot sekä kustannukset vastasyntyneen lapsen vaatettamisesta, hoi- 
tovälineistä sekä sairaanhoidosta ensimmäisen elinkuukauden aikana. Synnytyslaitoksella oloajan sekä sen jälkeisen ajan, enintään kuukauden, tilapäisen kodinhoitoavun kustannukset on myös luettu tarkasteltuihin synnytyskustannuksiin. Koska osa mainituista menoista on joko voitu maksaa rahana saadulla äitiysavustuksella tai vaatemenoista on vältytty ottamalla äitiysavustuspakkaus, lisättiin yhtenäisyyden vuoksi kaikille äitiysavustuspakkauksen saaneille lapsen vaatemenoihin sen arvoa vastaava summa $4500 \mathrm{mk}$. Muita luontoisetuja tai lahjoja ei sensijaan ole arvioitu rahaksi.

\section{Kokonaiskustannukset lapsen syntyessä}

Kokonaismenot raskaudesta ja synnytyksestä olivat kaikilla äideillä keskimäärin $28700 \mathrm{mk}$, mutta ensisynnyttäjillä huomattavasti enemmän, $37100 \mathrm{mk}$. Toisen ja sitä seuraavien lasten syntyessä ei menoissa enää ilmene kovin suuria eroja (taulu 1). Kun esikoisen ja seuraavien lasten syntyessä esim. hoitovarusteiden hankinnan tarve on erilainen, on tarkastelussa pidetty silmällä syntymäjärjestystä.

Perheiden suorittamat rahamenot eivät sellaisenaan kuvaa äidin ja lapsen saaman hoidon määrää tai tasoa, vaikka tällaiset erot saattavatkin olla osasyynä kokonaismenojen erilaisuuteen. Mahdollisten hoidon tasossa ilmenevien erojen valottamiseksi tarkastellaan seuraavassa synnytyskustannusten pienempiä menoeriä ja eräitä hoidon muita puolia kuten synnytyspaikkaa ja kodinhoitoapua. Edellytyksenä kalliimmalle - mahdollisesti joissakin tapauksissa paremmalle - hoidolle voi olla perheen varallisuus. Tämän eron tarkistamiseksi on aineisto jaettu täsmällisemmän varallisuusmitan puutteessa perheen päämiehen ammatin perusteella sosiaaliryhmiin. Kun Helsingin kaupungin tilastotoimiston käyttämää ryhmitystä on tähän asti lähinnä sovellettu kaupunkiväestöön, katsottiin parhaaksi jättää maanviljelijäperheet erilliseksi ryhmäkseen ottamatta kantaa heidän asemaansa varallisuusasteikolla. Aineiston pienuuden vuoksi on ryhmät yhdistetty seuraavassa kahteen ylimpään (I-II) ja kahteen alimpaan (III-IV) sosiaaliryhmään.

Paikkakunnittaisia eroja - Helsingin, muiden kaupunkien ja kauppaloiden sekä maalaiskuntien välillä — joudutaan tarkastelemaan jo siitäkin syystä, että näissä ryhmissä käytettiin erilaista otantasuhdetta, joten aineisto on vain painotuskertoimien avulla yhdistettävissä.

Kokonaismenojen lähemmässä tarkastelussa näiden tekijöiden mukaan (taulu 2) havaitaan tilastollisesti merkitsevät erot kustannuksissa esikoisen ja seuraavien lasten menoissa, kun perheet on luokiteltu menojen suuruuden mukaan kahteen luokkaan ja jakaantumien erot testattu $\chi^{2}$-testillä. Erikseen kummassakin syntymäjärjestysryhmässä ovat sosiaaliryhmien väliset erot merkitseviä kahdessa muussa paikkakuntaryhmässä mutta ei Helsingissä, jossa tapausten luku onkin pieni. Prosenttilukujen tarkastelu 
Ta u lu 1. Raskauden ja synnytyksen aiheuttamat kustannukset lapsen syntymäjärjestyksen ja kuntaryhmän mukaan.

Table 1. The cost of pregnancy and childbirth by birth order and commune group.

\begin{tabular}{|c|c|c|c|c|c|}
\hline \multirow{3}{*}{$\begin{array}{l}\text { Kuntaryhmä - } \\
\text { Commune group } \\
\text { Syntymäjärjestys } \\
\text { Birth order }\end{array}$} & \multicolumn{5}{|c|}{ Menoryhmä - Group of expenses } \\
\hline & $\begin{array}{l}\text { terveyden- } \\
\text { hoito - } \\
\text { care of } \\
\text { health }\end{array}$ & $\begin{array}{l}\text { matkat - } \\
\text { transport- } \\
\text { ation }\end{array}$ & $\begin{array}{l}\text { hoitova- } \\
\text { rusteet- } \\
\text { child-care } \\
\text { equipment }\end{array}$ & $\begin{array}{l}\text { kodin- } \\
\text { hoito - } \\
\text { domestic } \\
\text { help }\end{array}$ & $\begin{array}{l}\text { kokonais- } \\
\text { menot*- } \\
\text { total ex- } \\
\text { penditure* }\end{array}$ \\
\hline & \multicolumn{5}{|c|}{ keskiarvo, mk - mean, mks } \\
\hline
\end{tabular}

\section{Helsinki}

$\begin{array}{lrrrrrr}1 & (61) & 19400 & 1400 & 21800 & 200 & 43000 \\ 2 & (56) & 15000 & 1300 & 9.300 & 1500 & 27100 \\ 3- & (30) & 17800 & 1200 & 12000 & 2400 & 33400 \\ \text { kaikki - all } & (147) & 17400 & 1300 & 15000 & 1200 & 35000\end{array}$

Muut kaupungit ja kauppalat -

Other towns and market towns

$\begin{array}{lrrrrrr}1 & (91) & 14900 & 1100 & 24300 & 700 & 41000 \\ 2 & (91) & 13700 & 1300 & 13300 & 1700 & 30000 \\ 3- & (120) & 13800 & 1200 & 11100 & 2000 & 28100 \\ \text { kaikki - all } & (302) & 14100 & 1200 & 15800 & 1500 & 32600\end{array}$

Maalaiskunnat -

Rural communes

$\begin{array}{lrrrrrr}1 & (316) & 14700 & 3500 & 15400 & 900 & 34300 \\ 2 & (272) & 10600 & 2900 & 8500 & 2000 & 24000 \\ 3- & (576) & 9600 & 2800 & 6900 & 2700 & 22200 \\ \text { kaikki - all } & (1164) & 11300 & 3000 & 9600 & 2100 & 25900\end{array}$

Koko aineisto **

Total material **

$\begin{array}{lrrrrrr}1 & (468) & 15200 & 2600 & 18500 & 800 & 37100 \\ 2 & (419) & 12000 & 2200 & 9900 & 1900 & 26000 \\ 3- & (726) & 11700 & 2200 & 8600 & 2500 & 25000 \\ \text { kaikki - all } & (1613) & 12700 & 2300 & 11900 & 1800 & 28700\end{array}$

* Lukujen pyöristämisen vuoksi menojen summa eroaa kokonaismenoista. Because of the figures having been rounded, the sum of expenses differs from the total expenditure.

** Paikkakuntaryhmien painotettu keskiarvo. - Weighted mean for all commune groups.

sinänsä osoittaa alempaan sosiaaliryhmään kuuluvien käyttäneen vähemmän varoja lapsen syntymän yhteydessä. Maanviljelijäperheiden menot jakaantuvat tavalla, joka edustaa väliastetta kahden muista ammateista muodostetun sosiaaliryhmän välillä. Maalaiskuntien synnyttäjien suorittamat kustannukset eroavat merkitsevästi kaupunkilaisten kustannuksista. Sekä ensimmäisen että seuraavien lasten syntymisen aiheuttamat menot ovat \%-jakaantumien mukaan pienemmät maaseudulla kuin kaupungeissa. 
$\mathrm{Ta}$ u lu 2. Jakaantuminen raskauden ja synnytyksen aiheuttamien kokonaiskustannusten mukaan eri syntymäjärjestys- ja sosiaaliryhmissä, kuntaryhmittäin.

Table 2. Distribution according to total cost of pregnancy and childbirth in different birth-order categories and social classes, by commune group.

\begin{tabular}{|c|c|c|c|c|c|c|c|c|c|}
\hline \multirow{4}{*}{$\begin{array}{l}\text { Kuntaryhmä - } \\
\text { Commune group } \\
\text { Kustannukset, mk } \\
\text { Expenses, mks }\end{array}$} & \multicolumn{8}{|c|}{ Syntymäjärjestys - Birth order } & \multirow{4}{*}{$\begin{array}{l}\text { Kaikki } \\
\text { - All }\end{array}$} \\
\hline & & & 1 & & & & - & & \\
\hline & \multicolumn{8}{|c|}{ Sosiaaliryhmä - Social class } & \\
\hline & $\begin{array}{l}\text { I, } \\
\text { II }\end{array}$ & $\begin{array}{l}\text { III, } \\
\text { IV }\end{array}$ & $\begin{array}{l}\text { maan- } \\
\text { vilj. - } \\
\text { farm- } \\
\text { ers }\end{array}$ & $\begin{array}{l}\text { yht. - } \\
\text { total }\end{array}$ & $\begin{array}{l}\text { I, } \\
\text { II }\end{array}$ & $\begin{array}{l}\text { III, } \\
\text { IV }\end{array}$ & $\begin{array}{l}\text { maan- } \\
\text { vilj. - } \\
\text { farm- } \\
\text { ers }\end{array}$ & $\begin{array}{l}\text { yht. - } \\
\text { total }\end{array}$ & \\
\hline \multirow[t]{2}{*}{ A. $\begin{array}{r}\text { Helsinki } \\
\lesseqgtr 30000 \\
\lesseqgtr 30000\end{array}$} & $\begin{array}{l}(18) \\
11 \\
89\end{array}$ & $\begin{array}{c}(43) \\
30 \\
70\end{array}$ & $\begin{array}{l}(-) \\
-\end{array}$ & $\begin{array}{l}(61) \\
25 \\
75\end{array}$ & $\begin{array}{l}(38) \\
55 \\
45\end{array}$ & $\begin{array}{c}(48) \\
54 \\
46\end{array}$ & $\begin{array}{l}(-) \\
-\end{array}$ & $\begin{array}{l}(86) \\
55 \\
45\end{array}$ & $\begin{array}{c}(147) \\
42 \\
58\end{array}$ \\
\hline & $100 \%$ & $100 \%$ & - & $100 \%$ & $100 \%$ & $100 \%$ & - & $100 \%$ & $100 \%$ \\
\hline
\end{tabular}

B. Muut kaupungit

ja kauppalat -

Other towns and market towns

$<30000$

$\lesseqgtr 30000$

$\begin{array}{ccccccccc}(20) & (71) & (-) & (91) & (53) & (157) & (-) & (210) & (301) \\ 5 & 28 & - & 23 & 49 & 67 & - & 62 & 51 \\ 95 & 72 & - & 77 & 51 & 33 & - & 38 & 49 \\ 100 \% & 100 \% & - & 100 \% & 100 \% & 100 \% & - & 100 \% & 100 \%\end{array}$

C. Maalaiskunnat -

Rural communes

$<30000$

(62) (208)

(42)

(312)

(144)

(403)

(292) (839) (1151)

$>30000$

$\begin{array}{lllllllll}81 & 47 & 52 & 54 & 35 & 15 & 23 & 21 & 30\end{array}$

$\begin{array}{lllllllll}100 \% & 100 \% & 100 \% & 100 \% & 100 \% & 100 \% & 100 \% & 100 \% & 100 \%\end{array}$

Testit - Tests

Sosiaaliryhmä -

Social class:
A. Ei merkitsevä - Not significant

B. $\chi^{2}=5.6 ; \mathrm{P}<.02$

C. $\chi^{2}=21.0 ; \quad \mathrm{P}<.001$
A. Ei merkitsevä - Not significant

B. $\chi^{2}=5.3 ; \mathrm{P}<.025$

C. $\chi^{2}=23.8 ; \mathrm{P}<.001$
Syntymäjärjestys -

Birth order:

Kuntayhtymä (kaikki)

- Commune group (all):
A. $\chi^{2}=13.9 ; \quad \mathrm{P}<.001$
B. $\chi^{2}=39.4 ; \mathrm{P}<.001$
C. $\chi^{2}=117.3 ; \mathrm{P}<.001$

A-B. Ei merkitsevä - Not significant

A-C. $\chi^{2}=44.7 ; \quad \mathrm{P}<.001$

B-C. $\chi^{2}=39.3 ; \quad \mathrm{P}<.001$ 


\section{Hoitovarusteet}

Esikoista seuraavien lasten syntymisestä aiheutuneet pienemmät kustannukset johtuvat lähinnä hoitovarusteisiin käytetyn rahamäärän vähenemisestä - ilmeisesti onkin tavallista säästää esikoiselta jääneet varusteet seuraavien lasten varalle. Hoitovarusteisiin käytettiin ensimmäisen lapsen syntyessä keskimäärin $18500 \mathrm{mk}$ (taulu 1), melkein kaksinkertaisesti se summa, joka käytettiin seuraavien lasten vaatetus- ja muiden hoitovälineiden hankintaan. Äitiysavustus, $4500 \mathrm{mk}$, peittää näistä menoista esikoisilla vain noin neljäsosan, kaikilla lapsilla keskimäärin $40 \%$.

Esikoisen hoitovarustemenoissa ilmenee sosiaaliryhmien välillä eroja, jotka Helsingissä ovat tilastollisesti oireellisia, muissa paikkakuntaryhmissä merkitseviä (taulu 3). Ehkäpä ensimmäisen lapsen vaatettaminen ja varustaminen saa enemmän "huomiotaherättävän kulutuksen « muotoja kuin seuraavien, joiden kohdalla tyydytään vain välttämättömimmän vaatekerran valmistamiseen.

\section{Terveydenhoito}

Äidin ja lapsen terveydenhoidon tarpeen ei olettaisi sanottavasti muuttuvan synnytysten luvun mukaan eikä tilastollisesti merkitseviä eroja menoissa ilmennytkään muissa paikkakuntaryhmissä kuin maaseudulla (taulu 4). Kun raskauden — kuten sairauksienkin — vaatima tarpeellinen hoito on riippumaton perheen sosiaalisesta asemasta, herättää huomiota eri sosiaaliryhmien lääketieteelliseen hoitoon käyttämä poikkeava rahamäärä. Erot sosiaaliryhmien mukaan ovat tosin merkitseviä vain maalaiskunnissa sekä oireellisia helsinkiläisillä ensisynnyttäjillä ja muiden kaupunkikuntien uudelleensynnyttäjillä, mutta muissakin ryhmissä \%lukujen erot ovat samansuuntaisia. Kustannusten suuruus voi johtua käytetystä kalliimmasta hoidosta. Tällainen ero syntyy, jos äiti käyttää yksityislääkäriä tai synnyttää yksityishoidossa. Yksityislääkärillä neuvolan tarkastusten lisäksi ainakin kerran kävi Helsingissä lähes joka toinen, muissa paikkakuntaryhmissä hieman useampi synnyttäjä (taulu 5). Yksityislääkärissä käyminen eroaa sosiaaliryhmittäin oireellisesti Helsingissä ja merkitsevästi maalaiskunnissa, joten lääkärimenot ovat osasyynä koko terveydenhoitoon käytetyn rahamäärän vaihteluissa. Yksityislääkärille maksetut rahamäärät olivat kuitenkin kaikilla äideillä keskimäärin sangen pieniä, Helsingissä $1500 \mathrm{mk}$ ja maalaiskunnissa vain $900 \mathrm{mk}$.

Terveydenhoitomenojen suurimpia yksityisiä menoeriä olivat lääkemenot, helsinkiläisillä äideillä keskimäärin 3400 , maaseudun synnyttäjillä $2400 \mathrm{mk}$. Kun lääkkeiden tarpeen voitaisiin olettaa olevan yhtä suuren kaikilla odottavilla äideillä, panee sosiaaliryhmien välinen ero lääkemenoissa päättelemään, että varattomammat ovat voineet kustantaa itselleen vähemmän raskauden aikana ja sen jälkeen tarpeellisia lääkkeitä ja 
Ta ulu 3. Jakaantuminen hoitovarustemenojen mukaan eri syntymäjärjestys- ja sosiaaliryhmissä, kuntaryhmittäin.

T a ble 3. Distribution according to expenses for child-care equipment in different birth-order categories and social classes, by commune group.

\begin{tabular}{|c|c|c|c|c|c|c|c|c|c|}
\hline \multirow{4}{*}{$\begin{array}{l}\text { Kuntaryhmä - } \\
\text { Commune group } \\
\text { Kustannukset, mk } \\
\text { Expenses, mks }\end{array}$} & \multicolumn{8}{|c|}{ Syntymäjärjestys - Birth order } & \multirow{4}{*}{$\begin{array}{l}\text { Kaikki } \\
- \text { All }\end{array}$} \\
\hline & & & 1 & & & 2 & - & & \\
\hline & \multicolumn{8}{|c|}{ Sosiaaliryhmä - Social class } & \\
\hline & $\begin{array}{l}\text { I, } \\
\text { II }\end{array}$ & $\begin{array}{l}\text { III, } \\
\text { IV }\end{array}$ & $\begin{array}{l}\text { maan- } \\
\text { vilj. - } \\
\text { farm- } \\
\text { ers }\end{array}$ & $\begin{array}{l}\text { yht.- } \\
\text { total }\end{array}$ & $\begin{array}{l}\text { I, } \\
\text { II }\end{array}$ & $\begin{array}{l}\text { III, } \\
\text { IV }\end{array}$ & $\begin{array}{l}\text { maan- } \\
\text { vilj.- } \\
\text { farm- } \\
\text { ers }\end{array}$ & $\begin{array}{l}\text { yht. - } \\
\text { total }\end{array}$ & \\
\hline \multirow[t]{2}{*}{ A. $\begin{array}{r}\text { Helsinki } \\
\lesseqgtr 20000 \\
\lesseqgtr 20000\end{array}$} & $\begin{array}{c}(18) \\
28 \\
72\end{array}$ & $\begin{array}{c}(43) \\
53 \\
47\end{array}$ & $\begin{array}{l}(-) \\
- \\
-\end{array}$ & $\begin{array}{c}(61) \\
46 \\
54\end{array}$ & $\begin{array}{c}(38) \\
92 \\
8\end{array}$ & $\begin{array}{l}(48) \\
83 \\
17\end{array}$ & $\begin{array}{l}(-) \\
-\end{array}$ & $\begin{array}{l}(86) \\
87 \\
13\end{array}$ & $\begin{array}{c}(147) \\
70 \\
30\end{array}$ \\
\hline & $100 \%$ & $100 \%$ & - & $100 \%$ & $100 \%$ & $100 \%$ & - & $100 \%$ & $6 \quad 100 \%$ \\
\hline \multirow[t]{2}{*}{$\begin{array}{l}\text { B. Muut kaupungit } \\
\text { ja kauppalat - } \\
\text { Other towns and } \\
\text { market towns } \\
\leq 20000 \\
>20000\end{array}$} & $\begin{array}{l} \\
(20) \\
25 \\
75\end{array}$ & $\begin{array}{l}(71) \\
87 \\
13\end{array}$ & $\begin{array}{l}(-) \\
- \\
-\end{array}$ & $\begin{array}{l}(91) \\
41 \\
59\end{array}$ & $\begin{array}{l}(53) \\
77 \\
23\end{array}$ & $\begin{array}{c}(157) \\
83 \\
17\end{array}$ & $\begin{array}{l}(-) \\
-\end{array}$ & $\begin{array}{c}(210) \\
82 \\
18\end{array}$ & $\begin{array}{c}(301) \\
69 \\
31\end{array}$ \\
\hline & $100 \%$ & $100 \%$ & - & $100 \%$ & $100 \%$ & $100 \%$ & - & $100 \%$ & b $100 \%$ \\
\hline \multirow{2}{*}{$\begin{array}{l}\text { C. Maalaiskunnat- } \\
\text { Rural communes } \\
<20000 \\
\lesseqgtr 20000\end{array}$} & $\begin{array}{l}(62) \\
55 \\
45\end{array}$ & $\begin{array}{c}(208) \\
80 \\
20\end{array}$ & $\begin{array}{c}(42) \\
79 \\
21\end{array}$ & $\begin{array}{c}(312) \\
75 \\
25\end{array}$ & $\begin{array}{c}(144) \\
94 \\
6\end{array}$ & $\begin{array}{c}(403) \\
95 \\
5\end{array}$ & $\begin{array}{c}(292) \\
97 \\
3\end{array}$ & $\begin{array}{c}(839) \\
95 \\
5\end{array}$ & $\begin{array}{c}\left(\begin{array}{c}1 \\
151\end{array}\right) \\
88 \\
12\end{array}$ \\
\hline & $100 \%$ & $100 \%$ & $100 \%$ & $100 \%$ & $100 \%$ & $100 \%$ & $100 \%$ & $100 \%$ & $6 \quad 100 \%$ \\
\hline
\end{tabular}

Testit - Tests

\begin{tabular}{|c|c|c|}
\hline $\begin{array}{l}\text { Sosiaaliryhmä - } \\
\text { Social class: }\end{array}$ & $\begin{array}{ll}\text { A. } \chi^{2}=3.1 ; & \mathrm{P}<.10 \\
\text { B. } \chi^{2}=4.3 ; & \mathrm{P}<.05 \\
\text { C. } \chi^{2}=15.2 ; & \mathrm{P}<.001\end{array}$ & $\begin{array}{l}\text { A. Ei merk. - Not sig. } \\
\text { B. Ei merk. - Not sig. } \\
\text { C. Ei merk. - Not sig. }\end{array}$ \\
\hline $\begin{array}{l}\text { Syntymäjärjestys - } \\
\text { Birth order: }\end{array}$ & \multicolumn{2}{|c|}{$\begin{array}{ll}\text { A. } \chi^{2}=30.1 ; & \mathrm{P}<.001 \\
\text { B. } \chi^{2}=50.0 ; & \mathrm{P}<.001 \\
\text { C. } \chi^{2}=101.0 ; & \mathrm{P}<.001\end{array}$} \\
\hline $\begin{array}{l}\text { Kuntaryhmä (kaikki) } \\
\text { ( Commune group } \\
\text { (all): }\end{array}$ & \multicolumn{2}{|c|}{$\begin{array}{l}\text { A-B. Ei merkitsevä }- \text { Not significant } \\
\text { A-C. } \chi^{2}=48.1 ; \quad \mathrm{P}<.001 \\
\mathrm{~B}-\text { C. } \chi^{2}=72.7 ; \quad \mathrm{P}<.001\end{array}$} \\
\hline
\end{tabular}

suoja-aineita. Erot menoissa ovat tilastollisesti merkitseviä maalaiskunnissa ja helsinkiläisillä ensisynnyttäjillä, muissa ryhmissä \%-luvut ovat samansuuntaiset vaikkakaan erot eivät ole merkitseviä. Esikoistaan odottava äiti on yleensä käyttänyt lääkkeisiin enemmän rahaa kuin muut äidit (taulu 6). 
Ta ulu 4. Jakaantuminen terveydenhoitomenojen mukaan eri syntymäjärjestys- ja sosiaaliryhmissä, kuntaryhmittäin.

$T a b l e$ 4. Distribution according to expenses for health care in different birth-order categories and social classes, by commune group.

\begin{tabular}{|c|c|c|c|c|c|c|c|c|c|}
\hline \multirow{4}{*}{$\begin{array}{l}\text { Kuntaryhmä - } \\
\text { Commune group } \\
\text { Kustannukset, mk } \\
\text { Expenses, mks }\end{array}$} & \multicolumn{8}{|c|}{ Syntymäjärjestys - Birth order } & \multirow{4}{*}{$\begin{array}{l}\text { Kaikki } \\
-A l l\end{array}$} \\
\hline & & & 1 & & & & - & & \\
\hline & \multicolumn{8}{|c|}{ Sosiaaliryhmä - Social class } & \\
\hline & $\begin{array}{l}\text { I, } \\
\text { II }\end{array}$ & $\begin{array}{l}\text { III, } \\
\text { IV }\end{array}$ & $\begin{array}{l}\text { maan- } \\
\text { vilj. - } \\
\text { farm- } \\
\text { ers }\end{array}$ & $\begin{array}{l}\text { yht. - } \\
\text { total }\end{array}$ & $\begin{array}{l}\text { I, } \\
\text { II }\end{array}$ & $\begin{array}{l}\text { III, } \\
\text { IV }\end{array}$ & $\begin{array}{l}\text { maan- } \\
\text { vilj. - } \\
\text { farm- } \\
\text { ers }\end{array}$ & $\begin{array}{l}\text { yht. - } \\
\text { total }\end{array}$ & \\
\hline \multirow[t]{2}{*}{ 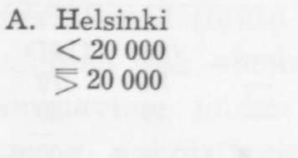 } & $\begin{array}{l}(18) \\
64 \\
36\end{array}$ & $\begin{array}{l}(43) \\
77 \\
23\end{array}$ & $\begin{array}{l}(-) \\
-\end{array}$ & $\begin{array}{l}(61) \\
70 \\
30\end{array}$ & $\begin{array}{l}(38) \\
71 \\
29\end{array}$ & $\begin{array}{c}(48) \\
77 \\
23\end{array}$ & $\begin{array}{l}(-) \\
-\end{array}$ & $\begin{array}{c}(86) \\
74 \\
26\end{array}$ & $\begin{array}{c}(147) \\
73 \\
27\end{array}$ \\
\hline & $100 \%$ & $100 \%$ & - & $100 \%$ & $100 \%$ & $100 \%$ & - & $100 \%$ & $100 \%$ \\
\hline \multirow[t]{2}{*}{$\begin{array}{l}\text { B. Muut kaupungit } \\
\text { ja kauppalat - } \\
\text { Other towns and } \\
\text { market towns } \\
<20000 \\
>20000\end{array}$} & $\begin{array}{c} \\
(20) \\
65 \\
35\end{array}$ & $\begin{array}{l}(71) \\
80 \\
20\end{array}$ & $\begin{array}{l}(-) \\
-\end{array}$ & $\begin{array}{c}(91) \\
77 \\
23\end{array}$ & $\begin{array}{l}(53) \\
75 \\
25\end{array}$ & $\begin{array}{c}(157) \\
86 \\
14\end{array}$ & $\begin{array}{l}(-) \\
- \\
-\end{array}$ & $\begin{array}{c}(210) \\
83 \\
17\end{array}$ & $\begin{array}{c}(301) \\
81 \\
19\end{array}$ \\
\hline & $100 \%$ & $100 \%$ & - & $100 \%$ & $100 \%$ & $100 \%$ & - & $100 \%$ & $100 \%$ \\
\hline \multirow[t]{2}{*}{$\begin{array}{l}\text { C. Maalaiskunnat - } \\
\text { Rural communes } \\
<20000 \\
\lesseqgtr 20000\end{array}$} & $\begin{array}{l}(62) \\
65 \\
35\end{array}$ & $\begin{array}{c}(208) \\
85 \\
15\end{array}$ & $\begin{array}{l}(42) \\
86 \\
14\end{array}$ & $\begin{array}{c}(312) \\
81 \\
19\end{array}$ & $\begin{array}{c}(144) \\
85 \\
15\end{array}$ & $\begin{array}{c}(403) \\
96 \\
4\end{array}$ & $\begin{array}{c}(292) \\
89 \\
11\end{array}$ & $\begin{array}{c}(839) \\
92 \\
8\end{array}$ & $\begin{array}{c}(1151) \\
89 \\
11\end{array}$ \\
\hline & $100 \%$ & $100 \%$ & $100 \%$ & $100 \%$ & $100 \%$ & $100 \%$ & $100 \%$ & $100 \%$ & $100 \%$ \\
\hline
\end{tabular}

Testit - Tests

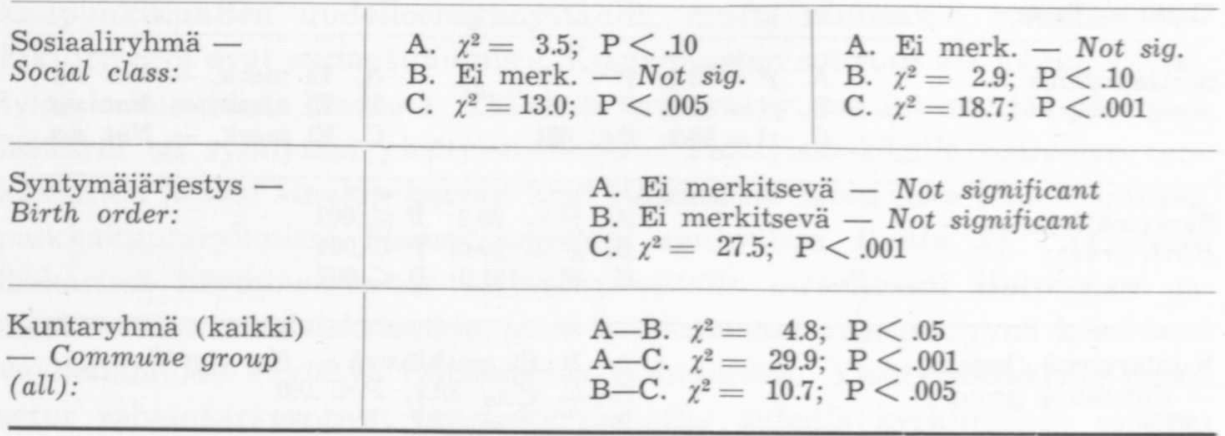

\section{Synnytyshoito}

Lähes kaikki kaupunkilaisäidit synnyttivät lapsensa laitoshoidossa, vain neljä kätilön hoitamaa kotisynnytystä oli muiden kaupunkien ja kauppaloiden tutkitussa äitiryhmässä. Maaseudulla sensijaan kätilön kotona hoitamia synnytyksiä oli $18 \%$ kaikista. Koska aineistosta puuttuvat Lapin 
T a u lu 5. Jakaantuminen yksityislääkärillä käymisen mukaan eri syntymäjärjestys- ja sosiaaliryhmissä, kuntaryhmittäin.

Table 5. Distribution according to consultation of private doctors in different birth-order categories and social classes, by commune group.

\begin{tabular}{|c|c|c|c|c|c|c|c|c|c|}
\hline \multirow{4}{*}{$\begin{array}{l}\text { Kuntaryhmä - } \\
\text { Commune group } \\
\text { Lääkärillä käymi- } \\
\text { nen - Cosultation } \\
\text { of doctors }\end{array}$} & \multicolumn{8}{|c|}{ Syntymäjärjestys - Birth order } & \multirow{4}{*}{$\begin{array}{l}\text { Kaikki } \\
-A l l\end{array}$} \\
\hline & & & 1 & & & & - & & \\
\hline & \multicolumn{8}{|c|}{ Sosiaaliryhmä - Social class } & \\
\hline & $\begin{array}{l}\text { I, } \\
\text { II }\end{array}$ & $\begin{array}{l}\text { III, } \\
\text { IV }\end{array}$ & $\begin{array}{l}\text { maan- } \\
\text { vilj. - } \\
\text { farm- } \\
\text { ers }\end{array}$ & $\begin{array}{l}\text { yht. - } \\
\text { total }\end{array}$ & $\begin{array}{l}\text { I, } \\
\text { II }\end{array}$ & $\begin{array}{l}\text { III, } \\
\text { IV }\end{array}$ & $\begin{array}{l}\text { maan- } \\
\text { vilj. - } \\
\text { farm- } \\
\text { ers }\end{array}$ & $\begin{array}{l}\text { yht. - } \\
\text { total }\end{array}$ & \\
\hline \multirow{4}{*}{$\begin{array}{l}\text { A. Helsinki } \\
\text { käynyt - } \\
\text { consulted } \\
\text { ei käynyt - } \\
\text { not consulted }\end{array}$} & (18) & $(43)$ & $(-)$ & $(61)$ & $(38)$ & $(48)$ & $(-)$ & $(86)$ & $(147)$ \\
\hline & 61 & 40 & - & 46 & 55 & 37 & - & 45 & 46 \\
\hline & 39 & 60 & - & 54 & 45 & 63 & - & 55 & 54 \\
\hline & $100 \%$ & $100 \%$ & - & $100 \%$ & $100 \%$ & $100 \%$ & - & $100 \%$ & $100 \%$ \\
\hline
\end{tabular}

B. Muut kaupungit

ja kauppalat -

Other towns and

market towns

(71) (-)

(91)

(53)

(157) (-) (210)

(301)

consulted

ei käynyt -

55

$69-66$

68

$\begin{array}{lll}57 & - & 60\end{array}$

61

not consulted

$\begin{array}{lllllllll}45 & 31 & - & 34 & 32 & 43 & - & 40 & 39\end{array}$

$100 \% 100 \%-100 \% \quad 100 \% \quad 100 \%-100 \% 100 \%$

C. Maalaiskunnat-

Rural communes

käynyt -

consulted

ei käynyt -

(62) (208)

(42) (312)

(143) (404) (292)

(839) (1 151)

not consulted

$\begin{array}{ccccc}81 & 63 & 60 & 66 & 63 \\ 19 & 37 & 40 & 34 & 37 \\ 100 \% & 100 \% & 100 \% & 100 \% & 100 \\ & \\ & \text { A. } \chi^{2}=2.9 ; \quad \mathrm{P}<.10 \\ \text { B. Ei merk. } \frac{\text { Not sig. }}{\text { C. } \chi^{2}=10.7 ;} \mathrm{P}<.005\end{array}$

$\begin{array}{lll}42 & 47 & 47\end{array}$

$\begin{array}{llll}37 & 58 & 53 & 53\end{array}$

48

$100 \% \quad 100 \% \quad 100 \% \quad 100 \% \quad 100 \%$

Testit - Tests

Sosiaaliryhmä -

Social class:
B. Ei merk. - Not sig.

C. $\chi^{2}=10.7 ; \mathrm{P}<.005$
A. $\chi^{2}=3.0 ; \mathrm{P}<.10$

B. Ei merk. - Not sig.

C. $\chi^{2}=15.6 ; \mathrm{P}<.001$
Syntymäjärjestys -

Birth order:
A. Ei merkitsevä - Not significant
B. Ei merkitsevä - Not significant
C. $\chi^{2}=32.8 ; \quad \mathrm{P}<.001$

Kuntaryhmä (kaikki)

- Commune group (all):
A-B. Ei merkitsevä - Not significant

A-C. Ei merkitsevä. - Not significant

B-C. $\chi^{2}=8.1 ; \quad \mathrm{P}<.005$ 
Taulu 6. Jakaantuminen lääkemenojen mukaan eri syntymäjärjestysja sosiaaliryhmissä, kuntaryhmittäin.

Table 6. Distribution according to expenses for medicines in different birth-order categories and social classes, by commune group.

\begin{tabular}{|c|c|c|c|c|c|c|c|c|c|}
\hline \multirow{4}{*}{$\begin{array}{l}\text { Kuntaryhmä - } \\
\text { Commune group } \\
\text { Kustannukset, mk } \\
\text { Expenses, mks }\end{array}$} & \multicolumn{8}{|c|}{ Syntymäjärjestys - Birth order } & \multirow{4}{*}{$\begin{array}{l}\text { Kaikki } \\
-A l l\end{array}$} \\
\hline & \multicolumn{3}{|r|}{1} & \multicolumn{5}{|c|}{$2-$} & \\
\hline & \multicolumn{8}{|c|}{ Sosiaaliryhmä - Social class } & \\
\hline & $\begin{array}{l}\text { I, } \\
\text { II }\end{array}$ & $\begin{array}{l}\text { III, } \\
\text { IV }\end{array}$ & $\begin{array}{l}\text { maan- } \\
\text { vilj.- - } \\
\text { farm- } \\
\text { ers }\end{array}$ & $\begin{array}{l}\text { yht. - } \\
\text { total }\end{array}$ & $\begin{array}{l}\text { I, } \\
\text { II }\end{array}$ & $\begin{array}{l}\text { III, } \\
\text { IV }\end{array}$ & $\begin{array}{l}\text { maan- } \\
\text { vilj. - } \\
\text { farm- } \\
\text { ers }\end{array}$ & $\begin{array}{l}\text { yht. - } \\
\text { total }\end{array}$ & \\
\hline \multirow[t]{2}{*}{$\begin{array}{l}\text { A. Helsinki } \\
<2000 \\
>2000\end{array}$} & $\frac{(18)}{100}$ & $\begin{array}{l}(43) \\
37 \\
63\end{array}$ & $\begin{array}{l}(-) \\
-\end{array}$ & $\begin{array}{l}(61) \\
26 \\
74\end{array}$ & $\begin{array}{l}(38) \\
37 \\
63\end{array}$ & $\begin{array}{l}(48) \\
44 \\
36\end{array}$ & $\begin{array}{l}(-) \\
-\end{array}$ & $\begin{array}{l}(86) \\
41 \\
59\end{array}$ & $\begin{array}{c}(147) \\
35 \\
65\end{array}$ \\
\hline & $100 \%$ & $100 \%$ & - & $100 \%$ & $100 \%$ & $100 \%$ & - & $100 \%$ & $100 \%$ \\
\hline \multirow[t]{2}{*}{$\begin{array}{l}\text { B. Muut kaupungit } \\
\text { ja kauppalat }- \\
\text { Other towns and } \\
\text { market towns } \\
\leq 2000 \\
>2000\end{array}$} & $\begin{array}{l} \\
(20) \\
30 \\
70\end{array}$ & $\begin{array}{l}(71) \\
37 \\
63\end{array}$ & $\begin{array}{l}(-) \\
-\end{array}$ & $\begin{array}{l}(91) \\
35 \\
65\end{array}$ & $\begin{array}{l}(53) \\
34 \\
66\end{array}$ & 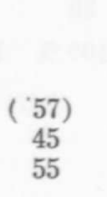 & $\begin{array}{l}(-) \\
-\end{array}$ & $\begin{array}{c}(210) \\
42 \\
58\end{array}$ & $\begin{array}{c}(301) \\
40 \\
60\end{array}$ \\
\hline & $100 \%$ & $100 \%$ & - & $100 \%$ & $100 \%$ & $100 \%$ & - & $100 \%$ & $100 \%$ \\
\hline \multirow{2}{*}{$\begin{array}{l}\text { C. Maalaiskunnat- } \\
\text { Rural communes } \\
\leq 2000 \\
>2000\end{array}$} & $\begin{array}{l}(62) \\
31 \\
69\end{array}$ & $\begin{array}{c}(208) \\
42 \\
58\end{array}$ & $\begin{array}{l}(42) \\
60 \\
40\end{array}$ & $\begin{array}{c}(312) \\
42 \\
58\end{array}$ & $\begin{array}{c}(144) \\
41 \\
59\end{array}$ & $\begin{array}{c}(403) \\
62 \\
38\end{array}$ & $\begin{array}{c}(292) \\
60 \\
40\end{array}$ & $\begin{array}{c}(839) \\
58 \\
42\end{array}$ & $\begin{array}{c}(1151) \\
54 \\
46\end{array}$ \\
\hline & $100 \%$ & $100 \%$ & $100 \%$ & $100 \%$ & $100 \%$ & $100 \%$ & $100 \%$ & $100 \%$ & $100 \%$ \\
\hline
\end{tabular}

Testit - Tests

\begin{tabular}{|c|c|c|}
\hline $\begin{array}{l}\text { Sosiaaliryhmä - } \\
\text { Social class: }\end{array}$ & $\begin{array}{l}\text { A. } \chi^{2}=9.9 ; \quad \mathrm{P}<.005 \\
\text { B. Ei merk. } \quad \mathrm{N} \text { ot sig. } \\
\text { C. } \chi^{2}=8.0 ; \quad \mathrm{P}<.02\end{array}$ & $\begin{array}{l}\text { A. Ei merk. }- \text { Not sig. } \\
\text { B. Ei merk. }- \text { Not sig. } \\
\text { C. } \chi^{2}=13.7 ; \mathrm{P}<.005\end{array}$ \\
\hline $\begin{array}{l}\text { Syntymäjärjestys - } \\
\text { Birth order: }\end{array}$ & \multicolumn{2}{|c|}{$\begin{array}{l}\text { A. } \chi^{2}=3.3 ; \quad \mathrm{P}<.10 \\
\text { B. Ei merkitsevä }- \text { Not significant } \\
\text { C. } \chi^{2}=21.6 ; \quad \mathrm{P}<.001\end{array}$} \\
\hline $\begin{array}{l}\text { Kuntaryhmä (kaikki) } \\
\text { (all): }\end{array}$ & \multicolumn{2}{|c|}{$\begin{array}{l}\text { A-B. Ei merkitsevä }- \text { Not significant } \\
\text { A-C. } \chi^{2}=19.2 ; \quad \mathrm{P}<.001 \\
\text { B-C. } \chi^{2}=17.1 ; \quad \mathrm{P}<.001\end{array}$} \\
\hline
\end{tabular}

läänin maalaiskunnat ja saaristokunnat, jää kotisynnytysten osuus pienemmäksi kuin maalaiskunnissa yleensä.

Synnytyshoidon kustannuksiin vaikuttaa ratkaisevasti synnytystapa, sillä kunnankätilö ei peri maksua muusta kuin hoitopaikkaan tulon aiheuttamista matkakuluista. Taulussa 1 esitetyt matkakulut voidaankin suu- 
rimmalta osalta laskea aiheutuneiksi synnytyslaitokselle menon ja sieltä palaamisen sekä kätilölle maksettujen matkakulujen aiheuttamiksi ja siten osaksi synnytyshoitomenoja. Synnytyslaitoksen etäisyys aiheuttaa siten lisäystä synnytyshoidon kustannuksiin - sen lisäksi, että pitkä matka voi kustannuksista riippumatta muodostua laitoshoidon saamisen esteeksi synnyttäjälle. Taulussa 7 onkin tästä syystä tarkasteltu synnytystapaa maalaiskuntien äitien keskuudessa erikseen lapsen järjestysluvun, sosiaaliryhmän ja lähimmän synnytyslaitoksen etäisyyden mukaan. Synnytyslaitoksen etäisyys vaikuttaa merkitsevästi synnytystapaan sekä ensimmäisen että seuraavien lasten syntyessä: lähempänä synnytyslaitosta asuvista ovat harvemmat synnyttäneet kotonaan. Vaikkakaan matkan vaikutusta ei ole testattu erikseen kunkin sosiaaliryhmän kohdalla, ilmaisevat \%-luvut samansuuntaista eroa lähes kaikissa sosiaaliryhmissä. Koti- ja laitossynnyttäjien suhteelliset osuudet eroavat kuitenkin lapsen syntymäjärjestyksen perusteella jyrkemmin kuin laitoksen etäisyyden mukaisessa luokittelussa. Esikoistaan synnyttävät äidit hakeutuvat sekä etäällä että lähellä asuessaan useammin laitoshoitoon kuin uudelleensynnyttäjät. Ensisynnyttäjien synnytystavan valinnassa eivät taulukon mukaan myöskään paina sosiaaliryhmien väliset oletetut varallisuuserot, sillä matkasta riippumatta ei ryhmien kesken ole merkitseviä eroja synnytystavassa. Sensijaan toisen ja sitä seuraavien lasten syntyessä synnytyslaitosmaksuista ja matkoista aiheutuvat kulut ovat ilmeisesti saaneet äidin valinnan useammin kallistumaan kotisynnytysten puolelle silloin, kuin perhe alempaan ammattiryhmään kuuluvana on tuntenut näiden menojen rasituksen suurempana. Toisaalta myös perinnäiset tavat erityisesti maanviljelijäkodeissa ovat voineet vaikuttaa kotisynnytyksen valintaan.

Kuvatut erot ensisynnyttäjän ja uudelleensynnyttäjän synnytystavassa ovat ilmeinen osoitus siitä, että maaseudun synnyttäjät ovat omaksuneet äitiyshuoltomme erään periaatteen. Laitossynnytyksen turvallisuutta ja tärkeyttä on erikoisesti korostettu ensimmäistä kertaa raskaana oleville äitiysneuvoloiden asiakkaille, ja laitossynnytys onkin perheen sosiaalisesta asemasta ja osittain pitkistäkin matkoista huolimatta heillä tavallinen. Ensimmäisen synnytyksen tapahduttua normaalisti uskaltaa kätilökin antaa äidin valita kotona synnyttämisen, jos laitossynnytys tuntuu perheestä taloudelliselta rasitukselta. Synnytyslaitosmaksujen ja laitokselle menon aiheuttamien matkakulujen korvaaminen suunnitellun sairausvakuutuksen osana toisi ilmeisesti muutoksen ainakin niiden äitien kohdalla, jotka nyt verrattain lähellä synnytyslaitosta asuen - alle $30 \mathrm{~km}$ etäisyydellä — kuitenkaan eivät voineet käyttää hyväkseen synnytyslaitosta, vaikkakin samalla etäisyydellä asuvista ensisynnyttäjistä lähes kaikki synnyttivät laitoksissa.

Synnytyslaitosmaksun suuruuteen vaikuttaa jossakin määrin myös hoidon pituus sekä se, oliko äiti laitoksessa yksityispotilaana. Ensisynnyttäjät viipyivät laitoksessa kauemmin kuin uudelleensynnyttäjät (taulu 8) ja 
Ta u lu 7. Jakaantuminen laitos- ja kotisynnytyksiin synnytyslaitoksen etäisyyden mukaan eri syntymäjärjestys- ja sosiaaliryhmissä, maalaiskunnat.

$T a b l e$ 7. Distribution according to hospital and home births by distance of domicile from maternity hospital in different birth-order categories and social classes (rural communes).

\begin{tabular}{|c|c|c|c|c|c|c|c|c|c|}
\hline \multirow{4}{*}{$\begin{array}{l}\text { Etäisyys - } \\
\text { Distance } \\
\text { Synnytyspaikka }- \\
\text { Place of childbirth }\end{array}$} & \multicolumn{8}{|c|}{ Syntymäjärjestys - Birth order } & \multirow{4}{*}{$\begin{array}{l}\text { Kaikki } \\
\text { - All }\end{array}$} \\
\hline & \multicolumn{4}{|c|}{1} & \multicolumn{4}{|c|}{$2-$} & \\
\hline & \multicolumn{8}{|c|}{ Sosiaaliryhmä - Social class } & \\
\hline & $\begin{array}{l}\text { I, } \\
\text { II }\end{array}$ & $\begin{array}{l}\text { III, } \\
\text { IV }\end{array}$ & $\begin{array}{l}\text { maan- } \\
\text { vilj.- } \\
\text { farm- } \\
\text { ers }\end{array}$ & $\begin{array}{l}\text { yht. - } \\
\text { total }\end{array}$ & $\begin{array}{l}\text { I, } \\
\text { II }\end{array}$ & $\begin{array}{l}\text { III, } \\
\text { IV }\end{array}$ & $\begin{array}{l}\text { maan- } \\
\text { vilj. - } \\
\text { farm- } \\
\text { ers }\end{array}$ & $\begin{array}{l}\text { yht. - } \\
\text { total }\end{array}$ & \\
\hline
\end{tabular}

A. Etäisyys alle $30 \mathrm{~km}-$

$\begin{array}{lccccccccc}\begin{array}{l}\text { Distance } \\ \begin{array}{l}\text { under 30 kms } \\ \text { laitossynnytys }\end{array}\end{array} & (36) & (138) & (21) & (195) & (101) & (262) & (248) & (611) & \text { (806) } \\ \begin{array}{l}\text { hospital birth } \\ \text { kotisynnytys }-\end{array} & 100 & 97 & 100 & 98 & 89 & 84 & 74 & 81 & 85 \\ \text { home birth } & - & 3 & - & 2 & 11 & 16 & 26 & 19 & 15 \\ & 100 \% & 100 \% & 100 \% & 100 \% & 100 \% & 100 \% & 100 \% & 100 \% & 100 \%\end{array}$

B. Etäisyys $30 \mathrm{~km}$ tai yli -

Distance

$30 \mathrm{kms}$ or over

laitossynnytys -

hospital birth

(26)

(66)

(21) (113)

(41) (132)

(44) (217)

$(330)$

kotisynnytys -

home birth

$\begin{array}{lllllllll}92 & 89 & 86 & 89 & 83 & 62 & 77 & 69 & 76\end{array}$

$\begin{array}{lllllllll}8 & 11 & 14 & 11 & 17 & 38 & 23 & 31 & 24\end{array}$

$\begin{array}{llllllllll}100 \% & 100 \% & 100 \% & 100 \% & 100 \% & 100 \% & 100 \% & 100 \% & 100 \%\end{array}$

Testit - Tests

\begin{tabular}{|c|c|c|}
\hline $\begin{array}{l}\text { Sosiaaliryhmä - } \\
\text { Social class: }\end{array}$ & $\begin{array}{l}\text { A. Ei merk. - Not sig. } \\
\text { B. Ei merk. - Not sig. }\end{array}$ & $\begin{array}{l}\text { A. } \chi^{2}=13.6 ; \quad \mathrm{P}<.005 \\
\text { B. } x^{2}=9.4 ; \quad \mathrm{P}<.01\end{array}$ \\
\hline $\begin{array}{l}\text { Laitoksen etäisyys }- \\
\text { Distance from hospital: }\end{array}$ & $\chi^{2}=10.2 ; \quad \mathrm{P}<.005$ & $\chi^{2}=12.6 ; \mathrm{P}<.001$ \\
\hline $\begin{array}{l}\text { Syntymäjärjestys } \\
\text { (kaikki) - Birth order } \\
\text { (all): }\end{array}$ & $\begin{array}{l}\text { A. } \chi^{2}=33.2 \\
\text { B. } \chi^{2}=16.6\end{array}$ & $\begin{array}{l}\mathrm{P}<.001 \\
\mathrm{P}<.001\end{array}$ \\
\hline
\end{tabular}

maaseudun äidit yleensä useampia vuorokausia kuin kaupunkilaiset, varsinkin helsinkiläiset, mihin saattaa olla syynä synnytystilojen ahtaus ja siitä johtuva äidin ja lapsen varhainen kotiin lähettäminen eräiltä kaupunkien synnytyslaitoksilta. Synnytyshoidon hintaa korottaa eräillä äideillä myös heidän saamansa yksityishoito synnytyslaitoksessa. Helsinkiläisistä tiedusteluun vastanneista oli $8 \%$ saanut tavallista yleisen osaston hoito- 
Taulu 8. Jakaantuminen synnytyslaitoksessa viipymisen mukaan eri syntymäjärjestys- ja sosiaaliryhmissä, kuntaryhmittäin.

$T a b l e$ 8. Distribution according to length of stay at maternity hospital in different birth-order categories and social classes, by commune group.

\begin{tabular}{|c|c|c|c|c|c|c|c|c|c|}
\hline \multirow{4}{*}{$\begin{array}{l}\text { Kuntaryhmä - } \\
\text { Commune group } \\
\text { Viipymisaika, } \\
\text { vrk. - } \\
\text { Length of stay, } \\
\text { days }\end{array}$} & \multicolumn{8}{|c|}{ Syntymäjärjestys - Birth order } & \multirow{4}{*}{$\begin{array}{l}\text { Kaikki } \\
-A l l\end{array}$} \\
\hline & & & 1 & & & & - & & \\
\hline & \multicolumn{8}{|c|}{ Sosiaaliryhmä - Social class } & \\
\hline & $\begin{array}{l}\text { I, } \\
\text { II }\end{array}$ & $\begin{array}{l}\text { III, } \\
\text { IV }\end{array}$ & $\begin{array}{l}\text { maan- } \\
\text { vilj. - } \\
\text { farm- } \\
\text { ers }\end{array}$ & $\begin{array}{l}\text { yht. - } \\
\text { total }\end{array}$ & $\begin{array}{l}\text { I, } \\
\text { II }\end{array}$ & $\begin{array}{l}\text { III, } \\
\text { IV }\end{array}$ & $\begin{array}{l}\text { maan- } \\
\text { vilj. - } \\
\text { farm- } \\
\text { ers }\end{array}$ & $\begin{array}{l}\text { yht. - } \\
\text { total }\end{array}$ & \\
\hline $\begin{array}{l}\text { A. Helsinki } \\
\qquad 7 \\
\sum 7\end{array}$ & $\begin{array}{l}(18) \\
17 \\
83\end{array}$ & $\begin{array}{l}(42) \\
21 \\
79\end{array}$ & $\begin{array}{l}(-) \\
-\end{array}$ & $\begin{array}{l}(60) \\
20 \\
80\end{array}$ & $\begin{array}{l}(38) \\
61 \\
39\end{array}$ & $\begin{array}{c}(48) \\
52 \\
48\end{array}$ & $\begin{array}{l}(-) \\
-\end{array}$ & $\begin{array}{c}(86) \\
56 \\
44\end{array}$ & $\begin{array}{c}(146) \\
41 \\
59\end{array}$ \\
\hline $\begin{array}{l}\text { B. Muut kaupungit } \\
\text { ja kauppalat - } \\
\text { Other towns and } \\
\text { market towns } \\
\leq 7 \\
>7\end{array}$ & $\begin{array}{l}100 \% \\
\\
(20) \\
15 \\
85\end{array}$ & $\begin{array}{c}(71) \\
23 \\
77\end{array}$ & $\begin{array}{l}(-) \\
- \\
-\end{array}$ & $\begin{array}{l}(91) \\
21 \\
79\end{array}$ & $\begin{array}{l}(52) \\
42 \\
58\end{array}$ & $\begin{array}{c}(151) \\
46 \\
54\end{array}$ & $\begin{array}{l}(-) \\
-\end{array}$ & $\begin{array}{c}(203) \\
45 \\
55\end{array}$ & $\begin{array}{c}(294) \\
37 \\
63\end{array}$ \\
\hline $\begin{array}{l}\text { C. Maalaiskunnat- } \\
\text { Rural communes } \\
<7 \\
\lesseqgtr 7\end{array}$ & $\begin{array}{l}100 \% \\
(61) \\
15 \\
85\end{array}$ & $\begin{array}{c}100 \% \\
\\
(193) \\
19 \\
81\end{array}$ & $\begin{array}{l}- \\
(39) \\
10 \\
90\end{array}$ & $\begin{array}{c}100 \% \\
(293) \\
17 \\
83\end{array}$ & $\begin{array}{c}100 \% \\
(124) \\
20 \\
80\end{array}$ & $\begin{array}{c}100 \% \\
(301) \\
31 \\
69\end{array}$ & $\begin{array}{c}- \\
(218) \\
30 \\
70\end{array}$ & $\begin{array}{c}100 \% \\
(643) \\
29 \\
71\end{array}$ & $\begin{array}{c}100 \% \\
\\
(936) \\
25 \\
75\end{array}$ \\
\hline & $100 \%$ & $100 \%$ & $100 \%$ & $100 \%$ & $100 \%$ & $100 \%$ & $100 \%$ & $100 \%$ & $100 \%$ \\
\hline
\end{tabular}

Testit - Tests

\begin{tabular}{l|l|l} 
Sosiaaliryhmä - & A. Ei merk. - Not sig. & A. Ei merk. - Not sig. \\
Social class: & B. Ei merk. - Not sig. & B. Ei merk. - Not sig. \\
& C. Ei merk. - Not sig. & C. $\chi^{2}=6.0 ; \mathrm{P}<.05$
\end{tabular}

Syntymäjärjestys -

Syntymäjärje
Birth order:

Kuntaryhmä (kaikki)

- Commune group (all):
B. Ei merk. - Not sig.
C. $\chi^{2}=6.0 ; \quad \mathrm{P}<.05$
A. $\chi^{2}=18.6 ; \quad \mathrm{P}<.001$
B. $\chi^{2}=15.3 ; \quad \mathrm{P}<.001$
C. $\chi^{2}=15.4 ; \quad \mathrm{P}<.001$

A-B. Ei merkitsevä - Not significant

A-C. $\chi^{2}=16.3 ; \quad \mathrm{P}<.001$

B-C. $\chi^{2}=17.5 ; \mathrm{P}<.001$

maksua kalliimman hoidon, muissa kuntaryhmissä yksityispotilaita oli vain $2 \%$. Kuitenkaan ei Helsingissä otantaa kohdistettu yksityisten synnytyssairaaloiden potilaisiin, joiden joukossa on saattanut olla myös neuvoloiden kirjoissa olevia äitejä. Yksityishoidossa olleista 12 helsinkiläisestä äidistä kuului yhdeksän I-II sosiaaliryhmään, muissa kaupungeissa samaan ryhmään kuului kuudesta synnyttäjästä neljä sekä maalaiskunnissa 21:stä 
äidistä 19 , joten tällä tavalla ylimmän sosiaaliryhmän terveydenhoitomenot saivat elintasosta johtuvaa etumatkaa. Yksityispotilaiden synnytyshoito tuli nimittäin hinnaltaan noin nelinkertaiseksi, esim. Helsingissä keskimäärin $23300 \mathrm{mk}: \mathrm{ksi}$, muiden synnyttäjien laitosmaksuihin (4 $800 \mathrm{mk})$ verrattuna. Kaikkien laitoksessa synnyttäneiden menot olivat Helsingissä keskimäärin $6300 \mathrm{mk}$, muissa kaupungeissa $5100 \mathrm{mk}$ ja maalaiskunnissa $5800 \mathrm{mk}$. Matkakulut olivat vastaavasti $1200 \mathrm{mk}, 1500 \mathrm{mk}$ ja $3000 \mathrm{mk}$.

\section{Kodinhoitoapu}

Perheiden kodinhoitoapuun äidin synnytyslaitoksella olon aikana käyttämä rahamäärä oli kaikilla perheillä keskimäärin vain parituhatta markkaa, $6 \%$ kaikista menoista. Menoja oli talouden ja lasten hoidon vuoksi aiheutunut Helsingissä joka viidennelle perheelle, mutta maalaiskunnissa $40 \%$ :lle kaikista. Palkatun avun lisäksi saivat monet perheet apua omaisiltaan, varsinkin ensisynnyttäjät, joilla kodinhoitoavun tarve ilmeisesti oli vähäisempi. Kodinhoitoapua - palkattua tai ilmaista - saaneita oli taulun 9 mukaan merkitsevästi runsaammin perheissä, joissa syntynyt lapsi oli toinen tai sitä seuraava sekä maanviljelijäkodeissa, joissa emännälle usein kuuluvien karjanhoitotehtävien vuoksi sijaisen saaminen onkin välttämätöntä. Kunnallisen kodinhoitajan sai kotiinsa avuksi paikkakuntaryhmittäin 13,16 ja $13 \%$ synnyttäjistä. Kodinhoitotoiminnan periaatteiden mukaisesti auttoivat kodinhoitajat pääasiassa useamman lapsen perheitä: suunnilleen joka viides perhe, jossa ennestään oli lapsia, sai kunnallisen kodinhoitajan apua. Pienituloisempaan III-IV sosiaaliryhmään kuuluvat perheet olivat etusijalla muihin sosiaaliryhmiin verrattuna tämän avun saamisessa.

\section{Synnyttäjän ansiotyö ja synnytyslepo}

Raskauden alussa kävi noin joka kolmas kaikista tiedusteluun vastanneista äideistä ansiotyössä kodin ulkopuolella. Ansiotyö oli tavallisinta helsinkiläisten ja harvinaisinta maaseudun synnyttäjien kohdalla (62 \% ja $24 \%$ ), kaikkein vähiten oli kodin ulkopuolella työssäkäyviä maanviljelijöiden vaimojen joukossa. Varsinkin molemmissa kaupunkiryhmissä vaimon ansiotyö oli aivan yleistä silloin, kun perheessä ei vielä ollut lainkaan lapsia $(92 \%$ ja $79 \%)$ ja maaseudullakin ensimmäistä lastaan odottavat äidit olivat runsaammin työssä kuin muut $(52 \%)$. Noin puolet odotusaikana työssä olleista, $17 \%$ kaikista äideistä, ilmoitti haastattelun ajankohtana joko jo palanneensa tai aikovansa lähitulevaisuudessa palata ansiotyöhön. 
$\mathrm{T}$ a u lu 9. Jakaantuminen kodinhoitoavun mukaan eri syntymäjärjestysja sosiaaliryhmissä, kuntaryhmittäin.

Table 9. Distribution according to domestic help in different birthorder categories and social classes, by commune group.

\begin{tabular}{|c|c|c|c|c|c|c|c|c|c|}
\hline \multirow{4}{*}{$\begin{array}{l}\text { Kuntaryhmä - } \\
\text { Commune group } \\
\text { Kodinhoitoapu - } \\
\text { Domestic help }\end{array}$} & \multicolumn{8}{|c|}{ Syntymäjärjestys - Birth order } & \multirow{4}{*}{$\begin{array}{l}\text { Kaikki } \\
\text { - All }\end{array}$} \\
\hline & & & 1 & & & & - & & \\
\hline & \multicolumn{8}{|c|}{ Sosiaaliryhmä - Social class } & \\
\hline & $\begin{array}{l}\text { I, } \\
\text { II }\end{array}$ & $\begin{array}{l}\text { III, } \\
\text { IV }\end{array}$ & $\begin{array}{l}\text { maan- } \\
\text { vilj. - } \\
\text { farm- } \\
\text { ers }\end{array}$ & total & $\begin{array}{l}\text { I, } \\
\text { II }\end{array}$ & $\begin{array}{l}\text { III, } \\
\text { IV }\end{array}$ & $\begin{array}{l}\text { maan- } \\
\text { vilj. - } \\
\text { farm- } \\
\text { ers }\end{array}$ & total & \\
\hline \multirow{3}{*}{$\begin{array}{l}\text { A. Helsinki } \\
\text { saanut - received } \\
\text { ei saanut - } \\
\text { not received }\end{array}$} & $\begin{array}{l}(18) \\
61\end{array}$ & $\begin{array}{c}(43) \\
33\end{array}$ & $\begin{array}{l}(-) \\
-\end{array}$ & $\begin{array}{c}(61) \\
41\end{array}$ & $\begin{array}{c}(38) \\
76\end{array}$ & $\begin{array}{c}(48) \\
81\end{array}$ & $\begin{array}{l}(-) \\
-\end{array}$ & $\begin{array}{c}(86) \\
79\end{array}$ & $\begin{array}{c}(147) \\
63\end{array}$ \\
\hline & 39 & 67 & - & 59 & 24 & 19 & - & 21 & 37 \\
\hline & $100 \%$ & $100 \%$ & - & $100 \%$ & $100 \%$ & $100 \%$ & - & $100 \%$ & $100 \%$ \\
\hline
\end{tabular}

B. Muut kaupungit

ja kauppalat -

Other towns and

market towns

(20)

$(71)$

saanut - received 55

(一) (91)

(53) (157)

$\begin{array}{lc}(-) & (210) \\ - & 76\end{array}$

(301)

ei saanut -

$\begin{array}{ccc}45 & 59 & - \\ 100 \% & 100 \% & -\end{array}$

$56 \quad 19$

$19 \quad 25$

$\begin{array}{lll}- & 24 & 34\end{array}$

not received $100 \% \quad 100 \%$

C. Maalaiskunnat-

Rural communes (62)

saanut - received 61

ei saanut -

(208) (42)

$100 \%$

$100 \% \quad 100 \%$

$100 \% \quad 100 \%$

not received

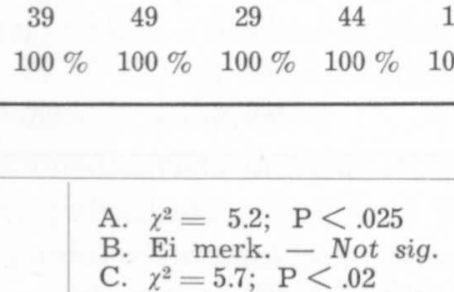

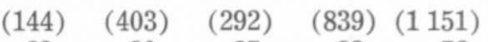

$\begin{array}{lllll}83 & 80 & 87 & 83 & 76\end{array}$

$\begin{array}{lllll}100 \% & 100 \% & 100 \% & 100 \% & 100 \%\end{array}$

Testit - Tests

Sosiaaliryhmä -

Social class:

B. Ei merk. - Not sig.

A. Ei merk. - Not sig.

C. $\chi^{2}=5.7 ; \mathrm{P}<.02$

B. Ei merk. - Not sig.

C. $\chi^{2}=5.1 ; \mathrm{P}<.10$

Syntymäjärjestys -

Birth order:
A. $\chi^{2}=24.7 ; \quad \mathrm{P}<.001$
B. $\chi^{2}=28.1 ; \quad \mathrm{P}<.001$
C. $\chi^{2}=93.4 ; \quad \mathrm{P}<.001$

Kuntaryhmä (kaikki)

- Commune group

A-B. Ei merkitsevä - Not significant

(all):

$\mathrm{A}-\mathrm{C} . \chi^{2}=10.3 ; \mathrm{P}<.001$

B-C. $\chi^{2}=11.5 ; \quad \mathrm{P}<.005$

Ansiotyön lopettamisen ajankohta ennen synnytystä riippuu ratkaisevasti siitä, aikooko äiti jatkaa työtään synnytyksen jälkeen (taulu 10). Voidaan ajatella, että pyrkimys työsuhteen säilyttämiseen ja sitä seuraavan palkallisen äitiysloman saamiseen on saanut äidit pysymään työssään 
$\mathrm{T}$ a u lu 10. Jakaantuminen ansiotyön lopettamisen ja sen aiotun aloittamisen ajankohdan mukaan, kuntaryhmittäin.

$T a b l e$ 10. Distribution according to date of ceasing wage-earning work and to date of intended return to wage-earning work, by commune group.

\begin{tabular}{|c|c|c|c|c|}
\hline \multirow{2}{*}{$\begin{array}{l}\text { Kuntaryhmä - } \\
\text { Commune group } \\
\text { Lopettamisen (aloitta- } \\
\text { misen) ajankohta en- } \\
\text { nen (jälkeen) synny- } \\
\text { tystä, viikkoa - } \\
\text { Distance of date of } \\
\text { ceasing (intended } \\
\text { return) to work from } \\
\text { childbirth, in weeks }\end{array}$} & \multicolumn{3}{|c|}{$\begin{array}{l}\text { Jakaantuminen työn lopettamisajankohdan } \\
\text { mukaan }- \text { Distribution according to date of } \\
\text { ceasing work }\end{array}$} & \multirow{2}{*}{$\begin{array}{l}\text { Jakaantuminer } \\
\text { työn aiotun } \\
\text { aloittamis- } \\
\text { ajankohdan } \\
\text { mukaan - } \\
\text { Distribution } \\
\text { according to } \\
\text { date of inten- } \\
\text { ded return to } \\
\text { work }\end{array}$} \\
\hline & $\begin{array}{l}\text { aikoi takaisin } \\
\text { työhön - } \\
\text { intended to } \\
\text { return to } \\
\text { work }\end{array}$ & $\begin{array}{l}\text { ei aikonut } \\
\text { takaisin työ- } \\
\text { hön- } \\
\text { did not intend } \\
\text { to return to } \\
\text { work }\end{array}$ & $\begin{array}{l}\text { kaikki - } \\
\text { all }\end{array}$ & \\
\hline
\end{tabular}

A. Helsinki

${ }^{4-3}-5$

B. Muut kaupungit ja kauppalat - Other towns and market towns

$-3$

$4-5$

$6-$

C. Maalaiskunnat -

Rural communes

$4-3$

6-
(49)

62

22

16

$100 \%$
(42)

29

17

54

$100 \%$
(91)

46

20

34

$100 \%$
(49)

4

12

84

$100 \%$

$\begin{array}{cccc}(68) & (81) & (149) & (68) \\ 53 & 7 & 28 & 7 \\ 31 & 11 & 20 & 16 \\ 16 & 82 & 52 & 77 \\ 100 \% & 100 \% & 100 \% & 100 \% \\ & & & \\ (124) & (150) & (274) & (124) \\ 56 & 15 & 33 & 18 \\ 23 & 5 & 13 & 19 \\ 21 & 80 & 54 & 63 \\ 100 \% & 100 \% & 100 \% & 100 \%\end{array}$

Testit - Tests

Työhön aikominen -

Intention to return to work:

A. $\chi^{2}=15.5 ; \mathrm{P}<.001$

B. $\chi^{2}=64.3 ; \mathrm{P}<.001$

C. $\chi^{2}=104.7 ; \mathrm{P}<.001$

\begin{tabular}{l|l|l}
\hline $\begin{array}{l}\text { Kuntaryhmä - } \\
\text { Commune group: }\end{array}$ & A-B. $\chi^{2}=8.9 ;$ & A-B. Ei merk. \\
& A-C. $\chi^{2}=13.1 ;$ & A-C. Ei merk. \\
& B-C. Ei merk. & B-C. Ei merk. \\
& - Not sig. & - Not sig. \\
\hline
\end{tabular}

aina synnytystä edeltäviin päiviinkin asti: 24,29 ja $18 \%$ työhönpalaavista äideistä paikkakuntaryhmittäin oli lopettanut työnsä vasta neljän synnytystä edeltävän päivän aikana. Helsinkiläisten työssäkääyvien äitien loma ennen synnytystä oli lyhin, työnsä lopetti korkeintaan kolme viikkoa 
ennen synnytystä $62 \%$ työhönpalaavista ja $29 \%$ kotiin jäävistä. Vastaavasti maaseudulla lasta odottavat työntekijät jäivät kotiin harvemmin vasta näin lähellä synnytystä ( 56 ja $15 \%$ ).

Nykyinen lainsäädäntö ei anna työntekijän synnytystä edeltävästä lepoajasta muuta ohjetta kuin sen, ettei raskaana olevaa naista saa pitää hänen terveydelleen vaarallisessa työssä. Uudessa sairausvakuutuskomitean mietinnössä ilmaistaan sensijaan välillisesti, ansionmenetyksen korvausta määriteltäessä, synnytyslevon toivotuksi pituudeksi kuusi viikkoa ennen ja kuusi viikkoa jälkeen synnytyksen. Tämä korvausajan määrittäminen 12 viikoksi johtuu lähinnä lääketieteellisistä seikoista, ja korvauksen suorittamisella sanotulta ajalta pyritään siihen, että raskaanaolevat voisivat jo hyvissä ajoin ennen synnytystä, mikäli mahdollista jo 6 viikkoa ennen sitä, turvautua asianmukaiseen hoitoon. Kuuden viikon pituisen synnytystä edeltävän lepoajan soveltaminen toisi olennaisen muutoksen nykyisin vallitsevaan tapaan jatkaa työtä huomattavasti myöhempään ajankohtaan ennen lapsen syntymää. Helsingissä vain $34 \%$, muissa kaupunkikunnissa 52 ja maalaiskunnissa $54 \%$ ođottavista äideistä oli nauttinut lepoaikaa kuusi viikkoa tai kauemmin.

Synnyttäjän lepoajasta synnytyksen jälkeen antaa lainsäädäntö selvän ohjeen. Synnytyslepo on teollisuusammateissa neljä, kauppaliikkeissä ja toimistoissa kuusi viikkoa. Tarkasteltaessa ansiotyön alkamisen ajankohtaa tutkimukseen osallistuneiden äitien kohdalla ilmeni, että työhön jo palanneilla tai palaamista suunnittelevilla - joita pyydettiin ilmoittamaan suunniteltu paluun ajankohta - synnytyksen jälkeinen lepoaika oli Helsingissä 4:1lä, muissa kaupungeissa ja kauppaloissa 7:1lä ja maalaiskunnissa jopa $18 \%$ :lla alle neljä viikkoa. Kuitenkin suurin osa ansioäideistä, paikkakunnittain 84,77 ja $63 \%$, oli voinut omistaa vähintään kuuden viikon ajan yksinomaan lapsensa hoitamiseen.

Enemmistö työhönpalaavista äideistä oli saanut palkkaa ainakin osalta poissaoloaikaa joko palkallisen äitiysloman tai sairasloman vuoksi. Työhönpalaavista kaupunkilaisäideistä $72 \%$ ja maaseudun synnyttäjistä $60 \%$ ilmoitti saaneensa palkkaa loman ajalta. Palkallisen loman saaminen oli hiukan yleisempää ammatiltaan I-II sosiaaliryhmään kuuluvien ansioäitien keskuudessa, mutta vastauksista ei ilmene, olisiko kotiin jääneillä äideillä ollut tilaisuus palkalliseen äitiyslomaan, jos he olisivat palanneet työhön. I-II sosiaaliryhmän ammateissa äitiysloma oli myös selvästi pitempi kuin alempaan ammattiryhmään kuuluvien työntekijöiden, edellisessä ryhmässä kolme neljästä äidistä sai lomaa vähintään 8 viikkoa, muissa ryhmissä näin pitkä loma oli harvinaisempaa (38\%).

Ansiotyöhön palaavien äitien palkkataso oli huomattavasti korkeampi kuin kotiin jääneiden. Helsinkiläisistä työhönpalaavista äideistä $59 \%$ sai nettopalkkaa veronvähennyksen jälkeen vähintään $25000 \mathrm{mk}$ kuukaudessa, kotiinjääneistä ainoastaan $40 \%$. Maaseudun ansiotyötään jatkavien ja kotiin jäävien kohdalla vastaavat luvut olivat 38 ja $9 \%$. Ansiotyötään 
jatkoivat useammin ammatiltaan I-II sosiaaliryhmään kuuluvat äidit kuin kahteen alempaan sosiaaliryhmään kuuluvat, joiden tulot ilmeisesti olisivat ansiotyössä käyden niin pienet, että kodin- ja lastenhoitokustannukset veisivät niistä suhteettoman suuren osan. Tämä havainto on sopusoinnussa tietojen kanssa helsinkiläisten naimisissaolevien naisten ansiotyöstä eri elämänvaiheissa. Ylempiin sosiaaliryhmiin kuuluvat naiset ovat työssä suhteellisen riippumatta perheen nuorimman lapsen iästä, kun sensijaan alempien ammattiryhmien äidit lopettavat työnsä lasten syntyessä ja palaavat runsaslukuisina työmarkkinoille vasta näiden vartuttua kouluikään (Hyvärinen 1960). Ansiotyön jatkaminen kohta sen jälkeen, kun perheeseen on syntynyt lapsi, on tavallisempaa parempituloisissa ammateissa, joihin usein myös kuuluu sosiaalisena etuna palkallisen ja pitemmän äitiysloman saaminen. Vaikkakaan pienituloiset ammatit eivät yleensä houkuttele äitiä jatkamaan työtään, joutuvat ansiotulonsa perheelleen välttämättömiksi katsovat äidit juuri näissä ryhmissä vaikeaan asemaan loman lyhyyden ja palkanmenetyksen johdosta. Ilmeisesti työntekijät joutuvat pitempää lomaa halutessaan katkaisemaan työsuhteensa ja hakeutumaan synnytyksen jälkeen uuteen työpaikkaan. Näille äideille ansionmenetyksen korvaaminen - mikäli suunniteltu sairausvakuutus tulisi sellaisen sisältämään - ja vastaavasti oikeus pitempään työstä poissaoloon työsuhdetta katkaisematta olisi nykyiseen tilanteeseen verrattuna parannus.

\section{Yhteenveto}

Raskauden ja synnytyksen aiheuttamat kustannukset erosivat perheillä, joissa syntynyt lapsi oli ensimmäinen, selvästi seuraavien lasten syntymisen aiheuttamista kustannuksista. Suurimpana syynä eroon olivat lapsen vaatettamisesta ja muista hoitovälineistä aiheutuneet kustannukset. Maaseudun synnyttäjien kustannukset olivat yleensä kaupunkilaisten vastaavia pienemmät. Lapsen syntymisen yhteydessä käyttivät eri sosiaaliryhmiin kuuluvat perheet - sosiaaliryhmät oli luokiteltu kahteen ylimpään ja kahteen alimpaan ryhmään "kaupunkilaisammattien « kohdalla sekä maanviljelijöihin - toisistaan poikkeavan määrän varoja. Koska eroon oli ainakin osittain syynä kalliimman yksityishoidon käyttäminen silloin, kun äitiysneuvolan tarjoama hoito ja yleisellä osastolla synnyttäminen tulisi kustannuksiltaan halvemmaksi, pyrittiin jossain määrin selvittämään myös synnyttäjän saaman hoidon laatua ja määrää. Tällöin todettiin, että eroja ilmeni mm. äidin lääkkeisiin käyttämässä rahamäärässä, synnytystavassa ja kodinhoitoavun saamisessa. Myös lapsen varusteisiin käytetyn rahamäärän vaihtelut osoittavat elintasosta johtuvia eroja, vaikkakaan mitään mittaa tarpeellisten ja ylellisyysmenojen erottamiseksi ei ole olemassa.

Ansiotyössä käyvän synnyttäjän saama synnytyslepo oli eräissä tapauksissa lyhyempi, kuin mitä lainsäädäntö näyttäisi edellyttävän. Varsinkin synnytystä edeltävä lepoaika oli ansiotyöhön takaisin aikovien kohdalla usein lyhyt. 


\title{
Kirjallisuus
}

Hyvärinen, Salme. Ammatissa toimivat naiset v. 1955. Tilastollisia kuukausitietoja Helsingistä 1960, 11.

Sairausvakuutuskomitean mietintö. Komiteanmietintö 1959, 6. Helsinki 1959.

Visuri, Elina. Tutkimus lapsen syntymisen perheelle aiheuttamista kustannuksista. Väestöpoliittinen tutkimuslaitos. Moniste. Helsinki 1960.

Visuri, Elina. Lapsen syntymisen aiheuttamat kustannukset. Sosiaalinen Aikakauskirja 1960, 11-12.

Yleinen terveyden- ja sairaanhoito 1958. Suomen virallinen tilasto XI: 6. Helsinki 1960.

\section{Summary:}

\section{The Cost of Pregnancy and Childbirth in Finland}

\author{
By ELINA VISURI \\ Population Research Institute
}

The social legislation of Finland at present in force provides for support to expectant mothers in the form of both material and medical help. Thus, maternity welfare centres have been set up in the country, each with a doctor and a trained midwife to be consulted by any mother residing here. The midwives are employed by towns and rural communes for giving advice to expectant mothers and helping them to take proper care of their newborn children. Communal midwives also attend to cases of delivery in the home, which in 1958 made $13 \%$ of all deliveries. The aid of the maternity welfare centres - given without cost to those applying for it - has in recent years reached as many as $95 \%$ of all mothers on an average. Owing to the fact that subsidies are paid to hospitals by the community, it has been possible to set the cost of deliveries effected in them fairly low.

A maternity allowance - usually in the form of a parcel containing a basic supply of baby clothing, or alternatively as an equivalent sum of money (4500 Finnish marks $=\$ 14)-$ is given to every mother who has consulted a doctor or a maternity welfare centre before the fifth month of her pregnancy.

For families with several children there is a body of trained communal housekeepers to help them during the mother's absence. Those of small means are to receive this help free of cost.

Mothers engaged in a wage-earning activity are safeguarded against too heavy work during pregnancy. Within present legislation they may be granted a »maternity leave», to begin, however, only after the child is born. It shall last four weeks for those following industrial occupations and six for those who work in offices and shops. As a rule no pay is attached to it. State and communal employees are entitled to a maternity leave of two months with full pay.

In the new health-insurance plan - submitted recently to the Council of State by a specially constituted committee - a compensation for the cost of childbirth is included as well as one for earnings lost during the necessary maternity leave. This again should, according to what the committee recommends, be granted for six weeks before and six weeks after childbirth. 
The Finnish Population and Family Welfare League »Väestöliitto», on being informed of the above proposal, has undertaken to investigate the question of the cost of childbirth in Finland under present possibilities for mothers of obtaining social benefits. To gain an idea of the situation, a questionnaire was sent in 1959 to about 1600 mothers of newborn children, covering nearly all parts of the country.

From the results it was evident, that the cost of pregnancy and childbirth for those families where the newborn child was the first, differed from that borne by families where it was a subsequent one. Principally, the diference consisted in the fact, that in the former case, due to the initial procuring of clothes and other equipment for the infant, the cost incurred was greater. The expenses for those mothers of newborn children that lived in rural areas proved to have been smaller than those for the corresponding urban mothers. In connection with childbirth, families belonging to different social groups - which comprised, according to the classification applied in the questionnaire, two groups (the shigher and the slowests) to represent the surban occupations», and that of the sfarmers» - spent quantities of means unequal in size between themselves. As the differences in this case were conditioned at least partly by the fact of a certain percentage of mothers having had themselves attended privately - and thus at a greater cost — although the care afforded by a maternity welfare centre and a delivery in the public ward of a hospital would have involved a smaller outlay, the investigators also tried to some extent to ascertain of what type and on what scale had been the attendance received by all the 'interviewed' mothers. They were able to establish distinct divergences between the mothers i.a. in the amounts of money spent on medicines, their places of delivery (»hospital or home births»), and in the extent to which they had received domestic help. Likewise, in the amounts of money spent on the child's equipment there appeared variations traceable to differences in standard of living. It must be remembered, however, that so far no criterion is known for distinguishing between expenditure on necessary and luxury articles.

The »maternity rest» accorded to those mothers who carried on a wage-earning activity had been in a number of cases shorter than what is provided for such mothers by the law. Notably this holds true of the rest interval previous to delivery, which turned out short for many mothers intending to return to their wage-earning activities. 